\title{
Searching for Factors Contributing to Students' Intention to Become a Leader: Internal Factors vs. Influence from Others
}

\author{
Eka Gatari and Nurul Arbiyah \\ Faculty of Psychology \\ Universitas Indonesia
}

\begin{abstract}
Leadership development within universities in Indonesia is still lacking, even though it is important as a starting point to develop future leaders. This study is aimed at exploring factors which might affect a students' intention to become a leader in a student organization, namely, attitude toward student leadership, subjective norms, perceived behavioral control, and leadership self-efficacy. Second- and third-year students $(N=286)$ from various faculties in a state university filled in a paper-based questionnaire containing newly constructed measurements, based on the theory of planned behavior by Ajzen and the theory of self-efficacy by Bandura. Data analysis using hierarchical multiple regression showed that only the subjective norms were related to the students' intention to lead student organizations ( $\beta=$ $.45, p<.01)$. This result implied that student organizations should also consider the potential leaders' peers, families, and significant others to persuade them to become leaders. Other implications were discussed further.
\end{abstract}

Keywords: attitude toward student leadership, leadership self-efficacy, perceived behavioral control, student's intention to become a leader, subjective norms

Pengembangan kepemimpinan dalam universitas di Indonesia masih kurang berkembang walaupun hal tersebut penting sebagai titik awal pengembangan calon pemimpin. Penelitian ini bertujuan melakukan eksplorasi terhadap faktor-faktor yang dapat berkontribusi pada intensi mahasiswa menjadi pemimpin dalam sebuah organisasi kemahasiswaan, seperti sikap terhadap kepemimpinan mahasiswa, norma subjektif, perceived behavioral control, dan leadership self-efficacy. Sejumlah 286 mahasiswa tahun kedua dan ketiga dari berbagai fakultas di sebuah universitas negeri mengisi kuesioner paper-based berisi alat ukur yang baru dibuat dengan berlandaskan pada teori planned behavior Ajzen dan teori self-efficacy Bandura. Analisis data menggunakan hierarchical multiple regression menunjukkan bahwa ketika semua variabel telah dikontrol, hanya norma subjektif yang berhubungan dengan intensi mahasiswa untuk memimpin sebuah organisasi kemahasiswaan $(\beta=.45, p<.01)$. Hasil ini mengimplikasikan bahwa organisasi kemahasiswaan perlu mempertimbangkan teman-teman, keluarga, dan orang penting lain bagi seorang calon pemimpin untuk dapat mempersuasi mereka menjadi pemimpin. Implikasi lebih lanjut didiskusikan dalam penelitian ini.

Kata kunci: sikap terhadap kepemimpinan mahasiswa, keyakinan kepemimpinan, perceived behavioral control, intensi mahasiswa menjadi pemimpin, norma subjektif

Leadership is an essential key to the successful functioning of an organization. Previous studies have shown that leadership behaviors can have an impact on task performance, organizational citizenship behavior (Piccolo \& Colquitt, 2006), and an employee's creativity performance (Therney, Farmer, \&

We extend special thanks to Universitas Indonesia which in part supported the authors with an Early Researcher Grant.

Correspondence concerning this article should be addressed to Eka Gatari, Fakultas Psikologi UI, Kampus Baru UI, Depok. E-mail: eka. gatari31@ui.ac.id
Graen, 1999). However, Indonesia is still behind in having leaders who are ready to fulfill organizational needs. A survey which has been conducted once every three years by a human resource consultancy in Indonesia, Daya Dimensi Indonesia (DDI), showed that in 2014 , only $25 \%$ of leaders and $12 \%$ of human resource professionals stated that they had highquality leadership in their organizations (DDI, 2014). The report also mentioned that those numbers were below those of the global norm, which showed that, globally, $40 \%$ of leaders and $25 \%$ of human resource 
professionals stated that they had high-quality leadership in their organization. This report showed that Indonesia needed better leadership development.

Leadership development should start when an individual is in his/her student years. Schneider, Paul, White, and Holcombe (1999) stated that the events which occur in an individual's developmental years can affect their future leadership behaviors in the workplace. The statement implied that the experiences which employees had received in their college or university years can make an impact on how they lead others in the workplace. Furthermore, student leaders can also have impacts on their community while they are still students, since they are already aware of, and desire, change (Mortensen et al., 2014).

Governments also recognise the importance of student leadership development. In Indonesia, The Ministry of Research, Technology, and Higher Education has stated that leadership is one of the essential skills needed from a graduate to be able to compete with others (Kementerian Riset, Teknologi, dan Pendidikan Tinggi, 2015). Unfortunately, The Ministry further noted that universities had not been fully able to develop graduates with these competitive skills. Furthermore, even though student leadership is crucial, research regarding issues for student leaders in Indonesia is still limited.

Dempster and Lizzio (2007) mentioned that even though there are a lot of studies on adult leadership, there is still much to learn about student leadership. Previous researches regarding leadership development in students have explored concepts such as a student's perception of leadership experience (Logue, Hutchens, \& Hector, 2005), the process of how a student identifies him/herself as a leader (Komives, Owen, Longerbeam, Mainella, \& Osteen, 2005), variables which were linked with socially responsible behaviors by student leaders, such as conversations with peers, mentoring by their faculties, and community service participation (Dugan \& Komives, 2010), and the effects of student leadership development programmes (Posner, 2009). There were also studies which explored the variables affecting leadership development, such as gender and ethnic identity (Kezar \& Moriarty, 2000), working whilst in college (Salisbury, Pascarella, Padgett, \& Blaich, 2012), and also previous leadership experience, and how important were leadership abilities for the respondents (Smart, Ethington, Riggs, \& Thompson, 2002). Based on previous studies, it was especially to determine how Smart et al. (2002) mentioned that previous leadership experience predicted how students perceived the importance of leadership development. Furthermore, Komives et al. (2005) stated that previous experience as a leader could help a student in forming his or her identity as a leader [sic].

Even though experience as a leader was seen as important, students might not search for opportuneties to have the experience to become leaders. Some student organizations showed their disappointment when only one candidate expressed any interest in becoming the leader of their organization (Ladarizka \& Priscilla, 2017; Shittanadi, 2017), citing apathy as a reason students did not want to join in as candidates in the election (Shittanadi). This showed that there may be reluctance from students to become leaders, which would certainly limit their development as future leaders. Being actual leaders would give them exposure to instances where they must manage others, solve their team problems as leaders, plan the steps needed to complete team tasks, and other related leader experiences. Because of their reluctance, they may well miss those leadership experiences.

With this issue as the principle concern, it was decided to explore the factors which would contribute to a student's intention to become a leader of a student organization. Intention is especially important since it can predict future behavior (Ajzen, 2006) and is assumed to be the immediate antecedent of behavior (Ajzen, 2012). Intention is seen as "...indications of how hard people are willing to try, of how much of an effort they are planning to exert, in order to perform the behavior" (Ajzen, 1991, p. 181). It has also been specifically reported to be the predictor of behaviors in both organizational and academic settings. As an example, intention to quit was found in a meta-analysis to be the predictor of turnover in organizations (Griffeth, Hom, \& Gaertner, 2000). Intention was also found to be the predictor of cheating behaviors in academic settings (Stone, Jawahar, \& Kisamore, 2009).

Since intention to lead might predict whether a student would become a leader of an organization, this study aimed to discover the variables which can contribute to a student's intention to become a leader (hereinafter abbreviated as SIBL).

The study especially focused on the reasons some students have the intention to become the leader of a student organization, and not of a committee or a one-time event, because it was assumed that an organization can give a more complex experience for a student. With this study, it was hoped to be able to give more information regarding how to encourage 
students to become leaders in their organizations.

Furthermore, this research was hoped to be able to enrich studies regarding student leaders. Even though studies on student leadership are emerging, there is still a need to understand leadership through a student's eyes, using instruments which were constructed utilizing his/her point of view (Dempster \& Lizzio, 2007). There is also limited research regarding the intention to lead, and that research was set in a non-academic setting, for example, Wymer, Self, and Findley (2008), which studied whether participants who like and participate in extreme sports would want to be involved in volunteer activities and lead an organization which could change society. They found that both male and female sensation-seekers were likely to desire to become leaders and have a preference for becoming leaders. With Dempster and Lizzio's (2007) statement in mind, used instruments were used which were developed utilising items constructed from elicitation data on students. With this method, this study was hoped to be able give a more accurate understanding of student leadership.

To explain SIBL, the theory of planned behavior (TPB) and self-efficacy was chosen as the basis of the study's hypothesis. TPB was the main theoretical framework chosen because it is regarded as a valuable theory to describe intention. The theory of planned behavior (Ajzen, 1991) has emerged as one of the most influential and popular conceptual frameworks for the study of human action (Ajzen, 2012), and can be a great framework as a basis to explain SIBL. TPB has also been used previously for leadership research in a workplace setting by Bommer, Rubin, and Baldwin (2004), albeit focusing on behavior, and not intention. TPB was developed as the extension to the theory of reasoned action (TRA) to address TRA's limitations in explaining behavior when people do not have full control (Ajzen, 1991), and TPB was found to explain intention better than TRA (Armitage \& Connor, 2001).

In the early formulation of TRA, behavioral intentions were formulated to be the function of the weighted sum of attitude toward the behavior in question and social normative belief (Ajzen \& Fishbein, 1970, 1973). In TPB, the three determinants of intention are attitude toward the behavior, or, in this research, attitude toward student leadership (hereinafter abbreviated to ASL), subjective norms (hereinafter abbreviated to $\mathrm{SN}$ ), and perceived behavioral control (hereinafter abbreviated to PBC) (Ajzen, 1991). In TPB, attitude is defined as, "the degree to which a person has a favorable or unfavorable evaluation or appraisal of the behavior in question" (Ajzen, 1991, p. 188) and $\mathrm{SN}$ is defined as, "...the perceived social pressure to perform or not to perform the behavior" (Ajzen, 1991, p. 188). PBC is an addition which differentiates TPB from TRA. PBC is defined as “...perceived ease or difficulty of performing the behavior and is assumed to reflect past experience as well as anticipated impediments and obstacles" (Ajzen, 1991, p. 188).

Each determinant had its function linked to belief. Attitude is affected by behavioral beliefs, SN is affected by normative beliefs, and PBC is affected by control beliefs (Ajzen). Ajzen further explained that attitude is the function of the belief that an object has a certain attribute (belief strength, or b), multiplied by whether the behavioral outcomes are valued as being positive or negative (outcome evaluation, or e). On the other hand, $\mathrm{SN}$ is a function of the possibility that certain important individuals or groups, or referents, approve or disapprove of certain behaviors (normative belief, or $\mathrm{n}$ ), multiplied by the person's motivation to comply (or $\mathrm{m}$ ) with the said referent. The last determinant, $\mathrm{PBC}$, is a function of the presence or absence of needed resources and opportunities (control belief, c) multiplied by the perceived power (or $p$ ) of the certain control factor which may facilitate or inhibit performance of the behavior.

While TPB in itself is already valuable in explaining SIBL, Ajzen (1991) stated that adding predicttors which might better explain intention was still acceptable. Therefore, self-efficacy was also added, which was also deemed important for the model. Self-efficacy is a construct which is closely linked to perceived behavioral control (Ajzen) but found to differ from it (Manstead \& van Eekelen, 1998). Furthermore, self-efficacy was also found better to predict intention to achieve good grades in an academic setting rather than attitude, subjective norms, or perceived control (Manstead \& van Eekelen). A metaanalysis by Armitage and Connor (2001) also shows that self-efficacy might explain variance in intention more than attitude, subjective norms, or perceived control.

The study focused on self-efficacy related to leadership itself, and not general self-efficacy. In many pieces of research consulted, though most were conducted in workplace settings, leadership self-efficacy (LSE) was found to be linked with various beneficial variables. Chemers, Watson, and May (2000) were some of the early researchers who explored LSE as a more specific form of self-efficacy. They 
found that leadership confidence contributed to leadership potential ratings and predicted future actual performance in work better than generalized constructs, such as self-esteem. Further research on LSE in a work setting also show LSE to be linked with leadership effectiveness (Anderson, Krajewski, Goffin, \& Jackson, 2008), an essential component of transformational leadership (Fitzgerald \& Schutte, 2009), a moderator to personality and leadership effectiveness (Ng, Ang, \& Chan, 2008), and the ability to lead change in a work setting (Paglis \& Green, 2002).

To put it briefly, this study was conducted so as to focus on a student's intention to lead a student organization. It was proposed that attitude to student leadership, subjective norms, perceived behavioral control, and leadership self-efficacy would be the predictors. The first three predictors were derived from the theory of planned behavior by Ajzen (1991), and leadership self-efficacy derived from the theory of Bandura (1997). This study was aimed at determining whether the proposed variables would predict a student's intention to lead a student organization. This study was intended to contribute to the current body of research by: (1) enriching studies of student leadership with measures constructed from the student's point of view; and (2) giving insights into the factors which should be noted to encourage a student to become the leader of a student organization.

\section{Attitude, Subjective Norms, Perceived Behavioral Control, and the Student's Intention to Lead}

As mentioned, the study focused on the theory of planned behavior (TPB) as a framework to explain SIBL. Using the TPB framework, it is argued that students need to have positive attitudes toward becoming leaders, have support from their significant others to become leaders, and have the feeling that they can control the behaviors which would lead them to become leaders. If students see that being leaders has undesirable outcomes which they want to avoid, such as poor academic grades or less time for personal activities (low ASL), SIBL might be low. With less support from their parents, peers, or lecturers (low $\mathrm{SN})$, SIBL might also be low. Lastly, if they want to become leaders but do not have time, control, or opportunity to do so (low PBC), their SIBL might also be affected.

The study examines those three determinants, but also argued that $\mathrm{SN}$ was the primary variable which can help determine SIBL. Armitage and Conner (2001) found that $\mathrm{SN}$ predicted intention as being weaker than the other variables within TPB, but in the study it appears that this might be different for students in Indonesia. The social pressure to do what others consider to be ideal appears even more relevant to attitudes in Indonesia, which, according to Hofstede, primarily has a collectivist culture (Hofstede, Hofstede, \& Minkov, 2010). In this culture, social norms form one of the principal factors which contribute to the emergence of SIBL. Previous research also shows that the people who interact with a student can be vital to his/her leadership development. Support, affirmation, and sponsorship from peers and adults are said to be critical factors in the early stages of student leadership development (Komives, Owen, Longerbeam, Mainella, \& Osteen, 2005). In a qualitative research by Logue, Hutchens, and Hector (2005), student leaders also described the to be such that a leader would be worthless without the people to whom they can relate.

Furthermore, group influences plays an important part in building leadership identity in students. Based on the model by Komives, Longerbeam, Owen, Mainella, and Osteen (2006), there are six stages in leadership identity development: awareness, exploration/engagement, leader identified, leadership differentiated, generativity, and integration/synthesis. Komives et al. (2006) explained that affirmation by others, especially adults, plays an important role during the first two stages of leadership, and in the third stage, others still play a part by becoming mentors and role models. Their ASL might still be forming during the first stage (awareness) through observation, and students might have a firmer stance on the second stage (exploration/engagement). Their PBC might also be forming during the second stage, when students engage in different activities. Based on those arguments, it is hypothesized that:

Hypothesis 1: Subjective norms contribute to students' intention to lead an organization, more than attitude and perceived behavioral control.

\section{Leadership Self-Efficacy and Student's Intention to Lead}

In addition to $\mathrm{SN}$, leadership self-efficacy (hereinafter abbreviated to LSE) is also considered as a necessary component in the process of understanding the development of SIBL. To understand LSE, self-efficacy should be explained first, since LSE is a specific form of self-efficacy. Self-efficacy is a theory 
developed by Albert Bandura and is defined as “... beliefs in one's capabilities to organize and execute the courses of action required to manage prospective functions" (Bandura, 1997, p. 2). Bandura also explained that self-efficacy affects how someone thinks, feels, acts, and motivate him/herself. Self-efficacy is also said to shape a person's life since he/she will tend to choose an activity or environment he/she thinks he/she could face (Bandura, 1997).

In a leadership context, self-efficacy was operationalized [sic] as leadership self-efficacy (LSE). LSE itself is an adaptive construct which can change based on the research's context. A definition from Paglis (2010) summarized previous researchers who explained LSE as a more general construct. Paglis stated that LSE was a "leader's confident judgment in his or her ability effectively to carry out the behaviors which comprise the leadership role" (p. 772). On the other hand, Paglis and Green (2002) defined LSE as being more focused on organizational change which is even more specific. In this study, the definition of LSE was adapted from Paglis the better to explain this research context, that is, the judgment of a person as to whether he or she could show specific behaviors related to the leadership role, in an organization within his/her university.

With those pieces of research as a basis, it is argued that leadership self-efficacy can play an important part in a student's leadership intention. Self-efficacy is said to influence thinking, emotion, motivation, and behavior (Bandura, 1997). This influence may then affect intention. Furthermore, recent research shows that LSE affects a student's motivation to lead (MTL), whether propelled by his/her intrinsic motivation (affective-identity MTL), prompted by an obligation or social duty to others (social normative MTL), or driven by the personal benefits which might accrue to a leadership position (calculative MTL) (Cho, Harrist, Steele \& Murn, 2015).

If a student has a high LSE, he/she would likely have more SIBL, since he/she believes that he/she could take on the challenges of leadership position with his/her abilities. On the other hand, students who do not have this belief would be more likely to become unsure as to whether they have the necessary abilities. This confidence or uncertainty could become the decisive factor when they think about their intentions regarding a leadership position.

With those arguments, it has been hypothesized that:

Hypothesis 2: Leadership self-efficacy contributed to a student's intention to become a leader.

Based on those hypotheses, the study proposes the model as shown in Figure 1.

\section{Methods}

\section{Study Design}

This is a cross-sectional and non-experimental study, aimed at predicting the effects of attitude on leadership, subjective norms, perceived behavioral control,

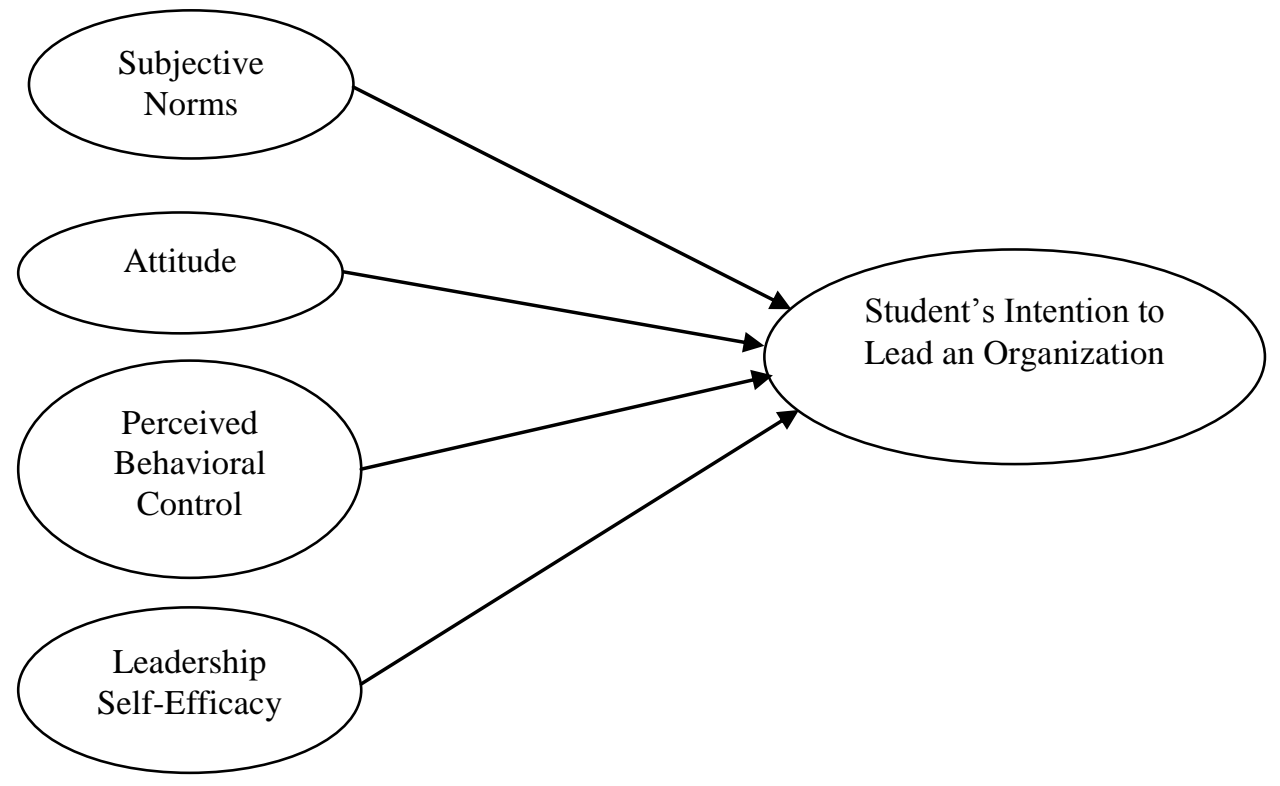

Figure 1. Research model. 
and leadership self-efficacy to SIBL.

\section{Participants}

To gather data for this research, undergraduates were recruited from various faculties in a state university. Participation was limited to second- and thirdyear students, who had more opportunities to become student leaders in an organization, since they already had the necessary network to become one and did not have to think about immanent graduation. Questionnaires were then administered face to face, and participants were assured that sample responses would remain anonymous and confidential.

Using accidental sampling, 288 students from multiple faculties participated in this study, but there were two outliers who were not included in the final analysis. From 286 students participating in this study, 149 (52.1\%) were second-year students and 137 $(47.9 \%)$ were third-year students. The participants ranged in age from 17 to 22 years old $(M=19.26$ years old, $S D=0.844) ; 204(71.3 \%)$ participants were female, and 80 (28\%) were male; 259 (90.6\%) students had experience on committees for campus events, while $26(9.1 \%)$ of the students had no such experience; $218(76.2 \%)$ of the students had been involved in formal student organizations, while 68 (23.8\%) had not participated in any student organization. Aside from formal student organizations, 51 $(17.8 \%)$ of the students had also been involved in off-campus organizations, such as local organizations in their home town and non-profit organizations, and $235(82.2 \%)$ students had not joined any such organization.

\section{Instruments}

All of the scales in this study were constructed specially for it. Ajzen (2006) stated that the TPB should be constructed in accordance with the behavior(s). Using a guide called the 'Constructing a Theory of Planned Behavior Questionnaire', developed by Ajzen (2006), a questionnaire was constructed, based on the TPB and which could be used to investigate the attitudes and beliefs underlying leadership behavior. It was deemed important to construct the measurement, since Dempster and Lizzio (2007) argued that leadership behaviors in students should be seen through the student's point of view, which might differ from those in a workrelated setting. A new measurement, constructed using the students' point of view would be a better choice to explain leadership intention within a student setting.

All of the items were constructed based on previous theories and experiences stated during elicitation through two focus group discussions conducted. Some of the students in the forum group discussions were students who led an organization, while some of the others had chosen not to be student leaders at that time. They were asked questions related to student leadership, such as the tasks and challenges they had faced when they became student leaders, the reasons why some of them felt incapable of becoming student leaders, what their attitude was toward student leaders, who had encouraged or impeded them when trying to become student leaders, and other related experiences. The participants came to the focus group discussion through invitation, and they were able to opt out of the discussions at any time. Their anonymity was ensured and they were given a notebook each, as a token of appreciation.

The items for the respective scales were then made, based on the results of the discussions. The items were then discussed within the research team. An independent source deemed to be an expert in each of the variables also double-checked the work to ensure the scales' validity. A readability test was also conducted with ten students, ensuring that the items were easily comprehended and appropriate for a student context. Based on the student's suggestions, several items were revised. Also, the reliability of each scale was measured, using Cronbach's alpha with 95 students as our pilot test respondents.

\section{Scale for Attitude Toward Student Leadership}

This scale was developed using a guide to Constructing a Theory of Planned Behavior Questionnaire, developed by Ajzen (2006) as the theoretical reference. Attitude Towards Student Leadership scale was used to test their evaluation (either positive or negative) of the attractiveness of student leadership. This was measured using two scales, an outcome evaluation scale and a behavioral belief strength scale. The items were constructed from the results of the FGD previously mentioned, and were mostly generated from the answers to the question, "Tell me what you think about the benefits and costs concerned with being a leader."

There were 17 items for each scale initially generated, but after considering the internal validity of each item in pilot and field studies, the final items used were seven for each scale. The outcome evalu- 
ation scale consisted of seven items using a 7-point Likert-type scale, bounded by $1=$ strongly disagree and $7=$ strongly agree. An example of a statement used on this scale is "Leading a student organization can make me have a big influence on others." The second scale, the behavioral belief strength scale, consisted of another seven 7-point Likert-type scale, bounded by $1=$ bad (scored as -3 ) and $7=\operatorname{good}($ scored as +3 ). A sample item for this measure is, "Having a big influence on others is a ... thing".

The score of attitude toward student leadership was obtained from the sum of the multiplication between outcome evaluation and belief strength. High scores on the scale indicated that students had a positive evaluation of student leadership. The internal consistency coefficient of the outcome evaluation scale was $\alpha=.852$, and belief strength scale was $\alpha=.807$, while the validity was based on expert judgment.

\section{Subjective Norms Scale}

A subjective norms scale was developed by referring to a Constructing a Theory of Planned Behavior Questionnaire by Ajzen (2006). The subjective norms scale was used to test if a student experiences social pressure to lead a student organization. Subjective norms were measured through two scales, a normative belief scale and a motivation to comply scale. Most of the items were generated from the result of the FGD previously mentioned, specifically from the answer to the question, "Is there anyone who thinks that having a leadership position would be good or bad for you?" and "Why would he or she thinks so?"

The initial items generated were six for each scale, and after reviewing the results from the pilot test, it was decided to keep all the items. The normative belief scale consists of six items using a 7-point Likerttype scale, bounded by $1=$ strongly disagree and $7=$ strongly agree. A sample for this scale is, "My father wants me to lead a student organization." The motivation to comply scale consists of six 7-point Likerttype items, bounded by $1=$ strongly disagree (scored as -3 ) and $7=$ strongly agree (scored as +3 ). One of the items in this scale was, "I want to comply with my father's wishes." The score of attitude toward student leadership was obtained from the sum of the multiplication between outcome evaluation and belief strength. High scores on the scale indicate that students had a strong social pressure to lead a student organization. The outcome evaluation scale results had $\alpha=.838$, and the belief strength scale had $\alpha=$ .862 , with expert judgment on the validity of methods.

\section{Perceived Behavioral Control (PBC) Scale}

Constructing a Theory of Planned Behavior Questionnaire based on one from Ajzen (2006) served as the reference to construct PBC a scale. PBC scale was used to test whether the students had easiness or difficulties concerning the leading of a student organization. PBC was measured through two scales, a control belief scale, and a control power belief scale. The item generation came from the results of the FGD previously mentioned, with most of them constructed from the answers to the question, "What kind of conditions would support or impede you in becoming a leader?"

The initial items generated were eight for each scale, and after reviewing the results from the pilot test, it was decided to eliminate two items from each scale. The control belief scale consisted of six items, with a 7-point Likert-type scale that was bounded by $1=$ strongly disagree, and $7=$ strongly agree. This scale had items such as "I have various positive experiences related to student organizations." The control power belief scale consisted of six items, with a 7-point with Likert-type scale bounded by $1=$ strongly disagree (scored as -3 ) and $7=$ strongly agree (scored as + 3). An example of this scale was, "Experiences can support success in leading a student organization." The score was obtained from the sum of the multiplication between control belief scale and control power belief scale. High scores on the scale indicated that students had a strong perceived control in overcoming difficulties as a leader in a student organization. The reliability of the control belief scale was $\alpha=.7$ and of the control power belief scale was $\alpha=.742$, whilst the validity was established by expert judgment.

\section{Leadership Self Efficacy Scale (LSE) Scale}

A LSE scale was used to test how confident students were, to do well in the task of being a student leader. A new test for the student's LSE was constructed, since previous surveys were orientated to a work setting, which might not well reflect LSE in students. The LSE scale was constructed based on a definition compiled by Paglis (2010), and the basic theory of self-efficacy proposed by Bandura (1997). Most of the items were generated by asking questions such as; "What kind of conditions would support or impede you in becoming a leader?"; "What are the characteristics of a student whom you think would become a good leader?", and; "What are the 
kinds of behaviors which would make you think a student was a good leader?"

The initial items for leadership self-efficacy were 26 in number, and they proved reliable and internally valid in the pilot test, using Cronbach's alpha. However, after running confirmatory factor analysis, 17 items which did not fit the model were eliminated. The final nine items in this scale had acceptable reliability in this study, with $\alpha=.89$. A Confirmatory Factor Analysis (CFA) was also conducted, which showed the Comparative Fit Index (CFI) $=.98$, the Goodness of Fit Index $(G F I)=.96$, and the RMSEA $=.05$. Those values indicate a good fit between the model and the observed data. The scale had nine items and used a 6-point Likert-type format, with $1=$ not appropriate and $6=$ appropriate. An item sample from this scale was, "I believe that I can influence others' opinions in the organization."

\section{Intention to Lead a Student Organization}

An intention scale was used to measure how much an individual had the desire to lead a student organization. Referring to the Constructing a Theory of Planned Behavior Questionnaire by Ajzen (2006), it needed only one item to measure intention with an 11-point Likert-type response scale. Therefore, the intention to lead a student organization scale was measured using a single item with 11-point Likerttype response scale, anchored at $0=$ strongly do not want to, and $10=$ strongly want to. This item asked the respondent to answer the question "How much do you want to lead a student organization?" High scores on the scale indicated that students had a strong intention to lead a student organization.

\section{Results}

The means, standard deviations, and inter-correlations of all major variables in the study are presented in Table 1.

Based on preliminary analysis using the Pearson correlation, LSE, ASL, SN, and PBC were positively correlated with SIBL. The data was then analyzed further using hierarchical regression to examine the hypothesis. The first step covered committee experience and membership of a student organization. In the second step, all of the predictor variables were entered. The results of this analysis indicated that the first model (committee experience and membership of a student organization) accounted for a significant amount of the variability in total intention, $R^{2}=.025, F(2,282)=3.566, p<.05$. The second model (LSE, ASL, SN, PBC, committee experience, and membership of student organization) accounted for a further significant variance in total intention, $\left(R^{2}=.272, F(6,278)=17.326, p<.001\right)$. Of these variables, the coefficients of subjective norms and committee experience were significant in predicting SIBL (subjective norms $\beta=.450, p=$ .000 ; committee experience $\beta=-.118, p=.035$ ).

These results suggested that only $\mathrm{SN}$ and committee experience were significantly affecting total intention to lead a student organization. The subjective norm had a direct positive effect on intention to lead student organization. After all of the variables were controlled, committee experience had a direct negative effect on intention to lead a student organization. Meanwhile, LSE, ASL, PBC, and membership of a student organization had no direct effect on intention to lead one. Therefore, Hypothesis 1, which stated that subjective norms contributed to a students' intention to lead an organization, more than attitude and perceived behavioral control, was accepted. On the other hand, Hypothesis 2, which stated that leadership self-efficacy contributed to a student's intention to become a leader, was rejected.

\section{Discussion}

The result of this study shows that only committee experience and SN can predict SIBL. This result supports Hypothesis 1, which stated that SN contributed to SIBL more than ASL and PBC, and rejects Hypothesis 2, which stated that LSE contributes to SIBL. The result gives a unique perspective on how students are so affected by others' opinions that their own views about a leadership position (ASL), their perception on whether they can control things (PBC), and their perceived ability to lead (LSE) were rendered irrelevant. This study supports Komives et al. (2005) statement that the support of others is needed to foster leadership in students, while it is not fully in line with the theory from Ajzen (1991). This research shows that $\mathrm{SN}$ is very influential, that other factors fade away into the background as reasons for their intention to lead. This result also showed different implications on SN's role in intention to what Armitage and Connor (2001) found in their meta-analysis study. This research shows that $\mathrm{SN}$ is very influential that other factors would fade away as a background to be the reason for their intention 
Table 1

Descriptive Statistics and Inter-Correlations of Study Variables

\begin{tabular}{lccccccc}
\hline \multicolumn{1}{c}{ Variable } & $M$ & $S D$ & 1 & 2 & 3 & 4 & 5 \\
\hline 1. LSE & 4.27 & .54 & - & - & - & - & - \\
2. ASL & 9.84 & 4.17 & $.328^{* * *}$ & - & - & - & - \\
3. SN & 1.19 & 3.85 & $.353^{* * *}$ & $.281^{* * *}$ & - & - & - \\
4. PBC & 5.39 & 3.47 & $.307^{* * *}$ & $.515^{* * *}$ & $.355^{* * *}$ & - & - \\
5. SIBL & 5.38 & 2.25 & $.223^{* * *}$ & $.222^{* * *}$ & $.496^{* * *}$ & $.265^{* * *}$ & - \\
\hline N & & & & & & &
\end{tabular}

Table 2

Hierarchical Multiple Regression Results Between Variables

\begin{tabular}{lcc}
\hline & $\mathrm{I} \beta$ & $\mathrm{II} \beta$ \\
\hline Committee Experience & -.084 & $-.118^{*}$ \\
Membership of a Student Organization & -.105 & .015 \\
LSE & & .032 \\
ASL & & .048 \\
SN & & $.450^{* * * *}$ \\
PBC & & .067 \\
$R^{2}$ & .025 & .272 \\
$\Delta R^{2}$ & .025 & .248 \\
$F$ & 3.566 & 17.326 \\
\hline Note. ${ }^{*} p<.05 ; * * p .01 ; * * *<.001$ & &
\end{tabular}

to lead. This result showed different implications on SN's role to intention that what Armitage and Connor (2001) found in their meta-analysis study. However, the result can still be explained by the nature of Indonesia's culture that was more collectivistic, which made others be one of the sources of someone's identity (Hofstede et al., 2010). Furthermore, previous research also showed that students could have more confidence to become a leader because they have a positive role model (Bowers, Rosch, \& Collier, 2015).

The result implies that the benefit of being the leader of a student organization should not be socialized and discussed only with potential candidates, but also with their peers, families, and significant others. This is especially important, since how students perceive their ability to lead a student organization does not have much influence on a students' intention to lead, when others state that being the leader of a student organization's would be bad for him/her. Even so, this study did not identify who exactly is able to influence students to change their intentions regarding becoming leaders. Further study is needed to identify which significant others would most influence a student to make his/her intention to become a leader more positive.

Bowers et al. (2015) stated that youth learn and listen to role models "who display positive characteristics (i.e., professional work ethics, interpersonal skills, and positive character traits)" (p. 112). This might also mean that if students do not have these positive role model, organizations can provide them with opportunities to meet with such role models, who exhibit the above-mentioned positive characteristics. However, further intervention plans must be meticulously designed, by making a pilot study, with several careful steps, such as identifying the beliefs which need to be changed, and also by proving the efficacy of the research measurement and design (Ajzen, 2015).

As was mentioned before, ASL, PBC, and LSE did not have any significant effect on intention, after the variables were controlled. ASL, PBC, and LSE might not have any effect on SIBL because they would not be the first thing which comes to mind when students are deliberating their intentions regarding leading a student organization. The sample of this study consisted of students in their second and third years, and they might well still develop their attitudes, PBC, and efficacy. They also might still depend on others' opinions as to whether they had done something right, and still further build their confidence. Komives et al. (2005) stated that students need to build their confidence first, before they can be independent of the effects of peer affirmation, which they can do by becoming leaders. Komives et al. (2006) also stated that self-confidence and recognition of strengths and weaknesses might come through exploring positions. In this case, the effects of those variables, especially PBC 
and LSE, might come after students have had some experience as leaders. Attitude regarding leadership positions might also be firmer after they have had those experiences. Future research should explore the effects of previous experience as a leader as a probable prerequisite for ASL, PBC, and LSE effects on SIBL.

Another unique result is the negative, significant effect of committee experience on SIBL after the predictors were controlled. This result may have emerged after students have heard stories, regarding leadership experience, from other students, during their activities in committees. There may have been stories regarding the difficult challenges which leaders may face, which can make students reluctant to become leaders. There is also the possibility that students found working as part of a committee was more enjoyable, rather than committing in an organization, thus making them reluctant to become leaders of an organization.

Referring to Komives et al. (2006), students in the exploration stage of their adult lives start to recognize their potential, and wanted to change something. Komives et al. also state that in that stage, affirmation from others still has an essential role. If there is no affirmation nor recognition from others suggesting that they can become leaders in an organization, and they are more motivated by others to be active in committee activities, students might get discouraged from trying for the positional role as leader. Future studies should explore the possibilities on how joining committees might impede SIBL.

\section{Limitations}

This study also has its limitations. First of all, the source of the sample in this study came only from a popular state university, which means that the results of this study might not be able to be generalized to other kinds of universities. Some of the issues which might affect the results of this study was that the workload students must face in this state university might be different that in other universities, which might affect the time students need to devote to their academic studies. Furthermore, the measurement scales used in this study were tested using students in this university. Thus, another pilot study, using students from various backgrounds, should be conducted to ensure that this measurement is reliable and valid in various academic settings. Future studies should consider adding other kinds of univer- sities, such as private universities or other state universities.

Secondly, the students were asked about their intentions regarding becoming leaders in student organizational settings. This result might be different if it were asked whether the respondents wanted to become leaders in event committees, or in volunteer activities, or other in organizations outside their university. Further studies are needed to know whether there are differences in results in other organizational contexts.

\section{Conclusions}

This study showed that subjective norms are important to be considered as the prime contributors for a student's intention to become a leader. Furthermore, it was demonstrated that his/her attitude towards a student leaders' perceived behavioral control, and leadership self-efficacy, does not have a significant effect on a student's intention to become a leader. This implied that organizations wanting to encourage students to become leaders should try to persuade his or her significant others to support the student in becoming a leader. Alternatively, organizations can consider mentoring potential leaders using positive role models. However, before deciding on the next step, another pilot test should be conducted, to ensure that the students receive the best form of intervention.

\section{References}

Ajzen, I. (1991). The theory of planned behavior. Organizational Behavior and Human Decision Processes, 50, 179-211. https://doi.org/10.1016/ 0749-5978(91)90020-t

Ajzen, I. (2015). The theory of planned behaviour is alive and well, and not ready to retire: A commentary on Sniehotta, Presseau, and Araújo-Soares. Health Psychology Review, 9, 131-137. https://doi.org/10.1080/17437199.2014.883474

Ajzen, I., \& Fishbein, M. (1970). The prediction of behavior from attitudinal and normative variables. Journal of Experimental Social Psychology, 6, 466-487. https://doi.org/10.1016/0022-1031 (70)90057-0

Ajzen, I. \& Fishbein, M. (1973). Attitudinal and normative variables as predictors of specific behaviors. Journal of Personality and Social Psychology, 27, 41-57. https://doi.org/10.1037/h0034440 
Ajzen, I. (2006). Constructing a theory of planned behavior questionnaire. Technical Report. Retrieved from http://people.umass.edu/ aizen/pdf/tpb.mea surement.pdf

Ajzen, I. (2012). The theory of planned behavior. In P. A. Van Lange, A. W. Kruglanski, \& E. T. Higgins. Handbook of theories of social psychology: Volume 1 (Vol. 1, pp. 438-459). London, UK: SAGE Publications Ltd. https://doi.org/10.4135/978144 6249215.n22

Anderson, D. W., Krajewski, H. T., Goffin, R. D., \& Jackson, D. N. (2008). A leadership self-efficacy taxonomy and its relation to leadership effectiveness. The Leadership Quarterly, 19, 545608. https://doi.org/10.1016/j.leaqua.2008.07.003

Armitage, C. J., \& Conner, M. (2001). Efficacy of the theory of planned behaviour: A meta-analytic review. British Journal of Social Psychology, 40, 471-499. https://doi.org/10.1348/014466601164939

Bandura, A. (1997). Exercise of personal and collective efficacy in changing societies. In A. Bandura (Eds.), Self-efficacy in changing societies (pp. 145). New York, NY: Cambridge Univer-sity Press.

Bommer, W. H., Rubin, R. S., \& Baldwin, T. T. (2004). Setting the stage for effective leadership: Antecedents of transformational leadership behavior. The Leadership Quarterly, 15, 195-210. https://doi.org/10.1016/j.leaqua.2004.02.012

Bowers, J. R., Rosch, D. M., \& Collier, D. A. (2015). Examining the relationship between role models and leadership growth during the transition to adulthood. Journal of Adolescent Research, 31, 96-118. https://doi.org/10.1177/07435584155 76570

DDI. (2014). Ready-now leaders meeting tomorrow's business challenges: Global leadership forecast 2014/2015, Indonesia. Retrieved from https:// www.ddiworld.com/glf2014

Chemers, M. M., Watson, C. B., \& May, S. T. (2000). Dispositional affect and leadership effectiveness: A comparison of self-esteem, optimism, and efficacy. Personality and Social Psychology Bulletin, 26, 267-277. https://doi.org/10.1177/ 0146167200265001

Cho, Y., Harrist, S., Steele, M., \& Murn, L.T. (2015). College student motivation to lead in relation to basic psychological need satisfaction and leadership self-efficacy. Journal of College Student Development, 56, 32-44. https://doi.org/10.1353/ csd.2015.0005

Dempster, N., \& Lizzio, A. (2007). Student leadership: Necessary research. Australian Journal of Education, 51, 276-285. https://doi.org/10.11 77/000494410705100305

Dugan, J. P., \& Komives, S. R. (2010). Influences on college students' capacities for socially responsible leadership. Journal of College Student Development, 51, 525-549. https://doi.org/10.13 53/csd.2010.0009

Griffeth, R. W., Hom, P. W., \& Gaertner, S. (2000). A meta-analysis of antecedents and correlates of employee turnover: Update, moderator tests, and research implications for the next millennium. Journal of Management, 26, 463-488. https:// doi.org/10.1177/014920630002600305

Hofstede, G., Hofstede, G. J., \& Minkov, M. (2010). Cultures and organizations: Software of the mind. New York, NY: McGraw Hill.

Kementerian Riset, Teknologi, dan Pendidikan Tinggi. (2015). Rencana strategis Kementerian Riset, Teknologi, dan Pendidikan Tinggi. Retrieved from http://isi-ska.ac.id/pengumuman/wp-content/ uploads/2015/05/128381838479.pdf

Kezar, A., \& Moriarty, D. (2000). Expanding our understanding of student leadership development: A study exploring gender and ethnic identity. Journal of College Student Development, 41, 55-69.

Komives, S. R., Longerbeam, S. D., Owen, J. E., Mainella, F. C., \& Osteen, L. (2006). A leadership identity development model: Applications from a grounded theory. Journal of College Student Development, 47, 401-418. https://doi.org/ 10.1353/csd.2006.0048

Komives, S. R., Owen, J. E., Longerbeam, S., Mainella, F. C., \& Osteen, L. (2005). Developing a leadership identity: A grounded theory. Journal of College Student Development, 46, 593-611. https:// doi.org/10.1353/csd.2005.0061

Ladarizka, T., \& Priscilla, J. (2017, November 29). Lagi-lagi calon tunggal, ada apa dengan BEM? [Sole candidate again, what is wrong with BEM?]. Retrieved from http://majalahketik.com/blog/20 17/11/29/calon-tunggal/

Logue, C. T., Hutchens, T. A., \& Hector, M. A. (2005). Student leadership: A phenomenological exploration of postsecondary experiences. Journal of College Student Development, 46, 393-408. https://doi.org/10.1353/csd.2005.0039

Manstead, A.S.R. \& van Eekelen, S.A.M. (1998). Distinguishing between perceived behavioral control and self-efficacy in the domain of academic achievement intentions and behavior. Journal of Applied Social Psychology, 28, 1375-1392. https:// doi.org/10.1111/j.1559-1816.1998.tb01682.x 
Mortensen, J., Lichty, L., Foster-Fishman, P., Harfst, S., Hockin, S., Warsinske, K., \& Abdullah, K. (2014). Leadership through a youth lens: Understanding youth conceptualizations of leadership. Journal of Community Psychology, 42, 447-462. https://doi.org/ 10.1002/ jcop.21620

Ng, K. Y., Ang, S., \& Chan, K. Y. (2008). Personality and leader effectiveness: A moderated mediation model of leadership self-efficacy, job demands, and job autonomy. Journal of Applied Psychology, 93, 733-743. https://doi.org/10.1037/ 0021-9010.93.4.733

Paglis, L. L. (2010). Leadership self-efficacy: Research findings and practical applications. Journal of Management Development, 29, 771-782. https:// doi.org/10.1108/02621711011072487

Paglis, L. L., \& Green, S. G. (2002). Leadership selfefficacy and managers' motivation for leading change. Journal of Organizational Behavior, 23, 215-235. https://doi.org/10.1002/job.137

Picollo, R.F., \& Colquitt, J.A. (2006). Transformational leadership and job behaviors: The mediating role of core job characteristics. Academy of Management Journals, 49, 327-340. https://doi. org/10.5465/amj.2006.20786079

Posner, B. Z. (2009). A longitudinal study examining changes in students' leadership behavior. Journal of College Student Development, 50, 551563. https://doi.org/10.1353/csd.0.0091

Salisbury, M. H., Pascarella, E. T., Padgett, R. D., $\&$ Blaich, C. (2012). The effects of work on leadership development among first-year college students. Journal of College Student Development,
53, 300-324. https://doi.org/10.1353/csd.2012.0021 Schneider, B., Paul, M. C., White, S. S., \& Holcombe, K. M. (1999). Understanding high school student leaders, I: Predicting teacher ratings of leader behavior. The Leadership Quarterly, 10, 609-636. https://doi.org/10.1016/S1048-9843(99)00038-7

Shittanadi, E. (2017, April 9). Calon tunggal, ketua ESA tidak akan dipilih melalui aklamasi [Sole candidate, ESA president would not be elected through acclamation]. Retrieved from http://de tak-unsyiah.com/headline/calon-tunggal-ketuaesa-tidak-akan-dipilih-melalui-aklamasi.html

Smart, J. C., Ethington, C. A., Riggs, R. O., \& Thompson, M. D. (2002). Influences of institutional expenditure patterns on the development of students' leadership competencies. Research in Higher Education, 43, 115-132. https://doi.org/10.5772/65269

Stone, T. H., Jawahar, I. M., \& Kisamore, J. L. (2009). Using the theory of planned behavior and cheating justifications to predict academic misconduct. Career Development International, 14, 221-241. https://doi.org/10.1108/13620430910966415

Tierney, P., Farmer, S. M., \& Graen, G. B. (1999). An examination of leadership and employee creativity: The relevance of traits and relationships. Personnel Psychology, 52, 591-620. https://doi. org/10.1111/j.1744-6570.1999.tb00173.x

Wymer, W., Self, D., \& Findley, C. S. C. (2008). Sensation seekers and civic participation: Exploring the influence of sensation seeking and gender on intention to lead and volunteer. International Journal of Nonprofit and Voluntary Sector Marketing, 13, 287-300. https://doi.org/10.1002/nvsm.330 